\title{
Pensonomonoor
}

2017, vol. 77, 147-159

http://dx.doi.org/10.12657/denbio.077.012

\author{
Piero Belletti, Diana Ferrazzini, Fulvio Ducci, Anna De Rogatis, \\ Marco Mucciarelli
}

\section{Genetic diversity of Italian populations of Abies alba}

Received: 17 July 2016; Accepted: 7 February 2017

\begin{abstract}
Silver fir (Abies alba) is a common tree species in the mountainous areas in Europe. A number of natural stands in the hilly regions of northern Europe represent relic populations. The aim of the research was to evaluate the diversity present in Italian populations of the species. Genetic diversity was assessed in 45 silver fir populations covering the species' distribution range in Italy, based on the allelic variation present at seven microsatellite loci (SSRs). A consistent level of intra-population variability was present. Several of the populations displayed signs of ongoing genetic erosion, and evidence for a recent bottleneck in some was identified. Populations from the eastern Alps and the Apennines were more variable than those sampled from the western Alps. About $8 \%$ of the overall genetic variance was found between populations, with the remainder representing variation present within the populations. The data suggested that the southern Apennines acted as a refugium during the most recent Ice Age, and that many of the populations from this area have remained isolated over a prolonged period. Smaller and more isolated populations have experienced genetic drift, whereas the larger ones have preserved a high level of diversity. Identification of genetically homogeneous regions could be informative for the management of genetic resources.
\end{abstract}

Keywords: Silver fir, genetic differentiation, glacial refugia, regions of provenance, SSR markers

Addresses: P. Belletti, University of Turin, DISAFA - Agricultural Genetics, e-mail: piero.belletti@unito.it; D. Ferrazzini, University of Turin, DISAFA - Agricultural Genetics, e-mail: diana.ferrazzini@yahoo.it

F. Ducci, CREA SEL - Forestry Research Centre, Arezzo, e-mail: fulvio.ducci@crea.gov.it

A. De Rogatis, CREA API - Honey Bee and Silkworm Unit, Bologna, e-mail: anna.derogatis@crea.gov.it M. Mucciarelli, University of Turin, Department of Life Sciences and Systems Biology,

e-mail: marco-mucciarelli@unito.it

\section{Introduction}

The Abies genus (Pinaceae) is represented by over 50 species, eight of which are endemic to the Mediterranean region and have a very limited distribution, namely Abies bornmülleriana Mattf., A. cephalonica Loudon, A. cilicica (Antoine \& Kotschy) Carrière,
A. equi-trojani (Asch. \& Sint. ex Boiss.) Mattf., A. nebrodensis Lojac. (Mattei), A. nordmanniana Steven (Spach), A. numidica de Lannoy ex Carrière and $A$. pinsapo Boiss, divided in the two subspecies tazaotana and marocana (Dering et al., 2014). A. borisii-regis Mattf. is thought to be a natural hybrid between $A$. alba and A. cephalonica (Vidaković, 1991). 


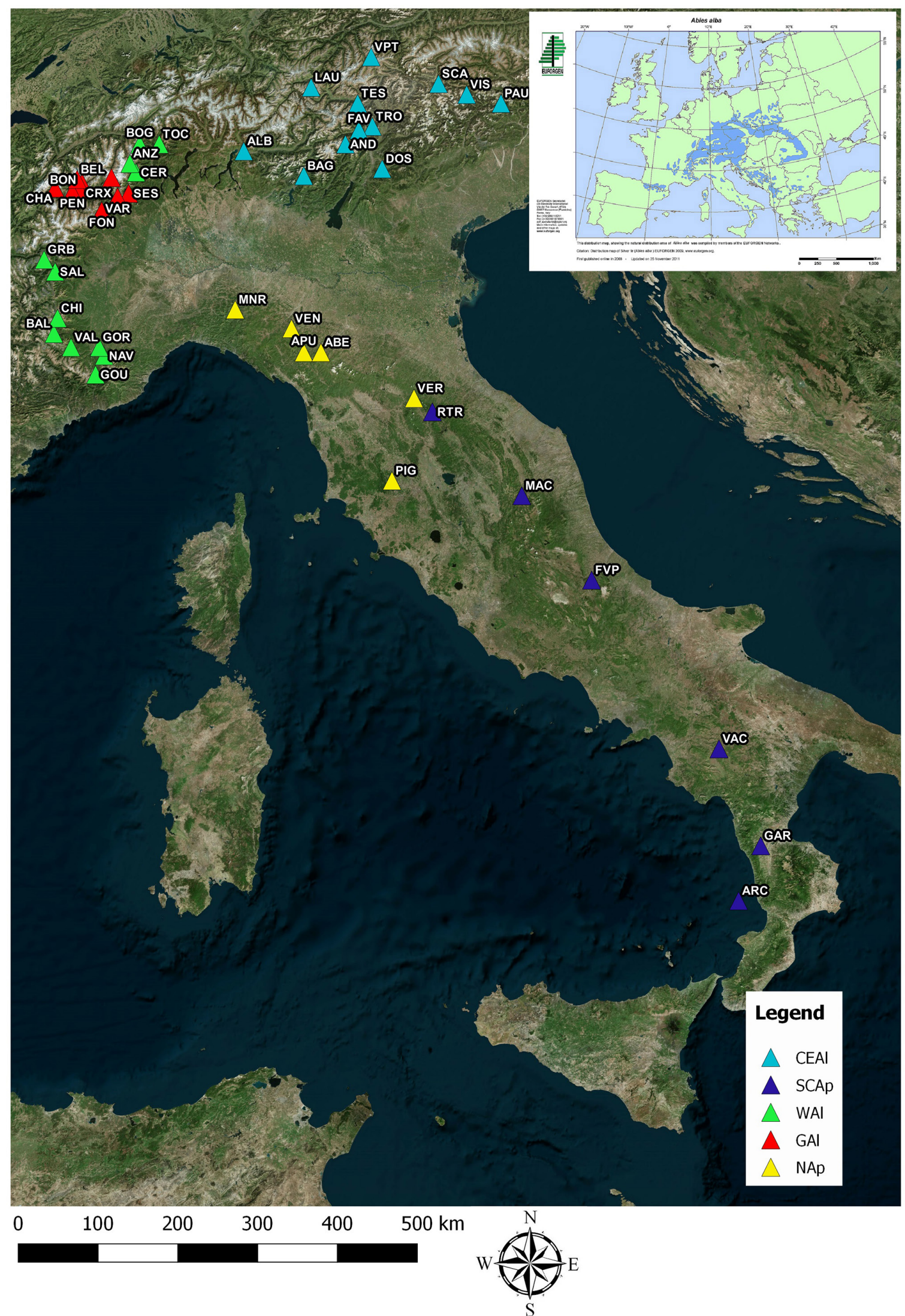

Fig. 1. Geographical distribution of 45 Italian populations of silver fir. WAl (western Alps), CEAl (central and eastern Alps), NAp (northern Apennines), GAl (Graian Alps), SCAp (central and southern Apennines). The European distribution of the species (according to EUFORGEN, http://www.euforgen.org/species/abies-alba/) is shown in the top right corner 
Silver fir (A. alba Mill.) is common in the European mountainous areas, with several relic populations occupying certain hilly regions of the northern Europe. Three effective refugia during the Holocene have been identified: one lies in the Apennines and the other two in the Balkans (Liepelt et al., 2009; Mosca et al., 2012; Cheddadi et al., 2014). According to Muller et al. (2007), the Apennine refugium should be considered as two sub-areas, one at their northern and the other at their southern end, with a further area taking in the Pyrenees and adjacent parts of north-eastern Spain. However, fir did not expand from refugia in the Pyrenees and Southern Italy (Cheddadi et al., 2014). A further refuge in southern France, speculated in the past, has been then excluded (Muller et al., 2007).

In Italy, the silver fir covers an area of about 68,000 ha, of which about two thirds represent pure stands (http://www.sian.it/inventarioforestale/jsp/ risultati_introb.jsp). The tree is relatively common in the central and eastern parts of the Alps, while its populations in the Apennines tend to be small and somewhat fragmented (Piovani et al., 2010); however, large stands are still be found in a few parts of the Apennines (Ducci et al., 1998). The cultivation of silver fir forests has a long tradition in Italy: the records show that both Franciscan and Benedictine monks were managing stands already 1,000 years ago as far apart as Tuscany in the northern part of the country and Calabria in the south. Its timber was used for ship construction by the Venetians and for supporting church roofs in both Florence and Rome (Ducci et al., 1998). In more modern times, its distribution has been strongly influenced by deforestation and/or replacement by European larch (Larix decidua).

Both anthropogenic activity and climate change exert a downwards pressure on the genetic diversity of natural forests. The pressure is particularly severe for marginal and peripheral populations (Jump \& Peñuelas, 2006; Reich \& Oleksyn, 2008; Leonardi et al., 2012). The long-term survival of such forests is heavily dependent on the preservation of intraspecific genetic diversity (Tessier du Cros et al., 1999; Kramer \& Havens, 2009).

The characterization of genetic diversity pattern within species and among populations is a fundamental condition to establish any program aimed at biodiversity preservation. Genetic markers are basic to supply information on the genetic structure of populations, to analyse the pattern of within-species variability distribution (Pautasso, 2009), and to support the management of seed supply, taking into account the limits to be respected for seed collection (Escudero et al., 2003). In particular, knowledge of genetic variation should be the basis for ecological restoration actions (Väli et al., 2008). This is even more important where the preservation of local, marginal and well adapted and/or differentiated gene pools must be achieved through the implementation of such small and probably inbreeded populations (Rice \& Emery, 2003; Frankham, 2005; Lefèvre et al., 2012). As a consequence, the objective is focal not only for scattered and rare species, but also for those characterised by wide distribution and that could seem less sensitive to genetic erosion (Eckert et al., 2008; Montoya, 2008).

The purpose of the present study was to assess the genetic variation retained in a number of silver fir populations sampled from various locations across Italy, based on genotyping at a set of nuclear microsatellite loci. Results are also discussed in the light of the European Directive 1999/105/CE, which deals with marketing of forest reproductive material and defines principles and criteria on which the forest seed chain should be based.

\section{Material and methods}

\section{Silver fir population sampling}

A set of 45 populations of silver fir was selected, covering the natural range of the species in Italy (Fig. 1, Table 1). Most of these populations are thought to

Table 1. Site characteristics of the 45 sampled Italian silver fir populations. The rainfall and temperature records are means calculated from at least five years of data

\begin{tabular}{|c|c|c|c|c|c|c|c|}
\hline Code & Population & Geographical region & Latitude $\mathrm{N}$ & Longitude E & $\begin{array}{c}\text { Sampling area } \\
\text { elevation } \\
\text { (m s.l.m.) }\end{array}$ & $\begin{array}{l}\text { Annual (sum- } \\
\text { mer) rainfall } \\
(\mathrm{mm})\end{array}$ & $\begin{array}{c}\text { Annual average } \\
\text { temperature } \\
\left({ }^{\circ} \mathrm{C}\right)\end{array}$ \\
\hline GOU & Gouta & Western Alps & $43^{\circ} 56^{\prime}$ & $7^{\circ} 36^{\prime}$ & $1000-1300$ & $1510(286)$ & 11.8 \\
\hline NAV & Navette & Western Alps & $44^{\circ} 07^{\prime}$ & $7^{\circ} 43^{\prime}$ & $1400-1600$ & $1320(230)$ & 8.2 \\
\hline GOR & Prel-Buscaiè & Western Alps & $44^{\circ} 12^{\prime}$ & $7^{\circ} 39^{\prime}$ & $1000-1200$ & $1290(269)$ & 10.6 \\
\hline VAL & Terme di Valdieri & Western Alps & $44^{\circ} 12^{\prime}$ & $7^{\circ} 16^{\prime}$ & $1400-1600$ & $1260(220)$ & 8.1 \\
\hline BAL & Pietraporzio & Western Alps & $44^{\circ} 20^{\prime}$ & $7^{\circ} 02^{\prime}$ & $1300-1400$ & 1000 (193) & 5.4 \\
\hline $\mathrm{CHI}$ & Chiotspars, Prazzo & Western Alps & $44^{\circ} 29^{\prime}$ & $7^{\circ} 05^{\prime}$ & $900-1100$ & $980(140)$ & 5.9 \\
\hline SAL & Salza di Pinerolo & Western Alps & $44^{\circ} 56^{\prime}$ & $7^{\circ} 03^{\prime}$ & $1200-1400$ & $1130(129)$ & 5.4 \\
\hline GRB & Gran Bosco Salbertrand & Western Alps & $45^{\circ} 03^{\prime}$ & $6^{\circ} 54^{\prime}$ & $1600-1800$ & $760(180)$ & 6.2 \\
\hline FON & Fondo & Western Alps & $45^{\circ} 31^{\prime}$ & $7^{\circ} 41^{\prime}$ & $1100-1200$ & $1210(320)$ & 4.8 \\
\hline SES & Campello & Western Alps & $45^{\circ} 41^{\prime}$ & $8^{\circ} 03^{\prime}$ & $1400-1600$ & $1580(450)$ & 7.1 \\
\hline
\end{tabular}


Piero Belletti et al.

\begin{tabular}{|c|c|c|c|c|c|c|c|}
\hline Code & Population & Geographical region & Latitude N & Longitude E & $\begin{array}{c}\text { Sampling area } \\
\text { elevation } \\
\text { (m s.l.m.) }\end{array}$ & $\begin{array}{l}\text { Annual (sum- } \\
\text { mer) rainfall } \\
\text { (mm) }\end{array}$ & $\begin{array}{c}\text { Annual average } \\
\text { temperature } \\
\left({ }^{\circ} \mathrm{C}\right)\end{array}$ \\
\hline CER & Cervatto & Western Alps & $45^{\circ} 53^{\prime}$ & $8^{\circ} 09^{\prime}$ & $1000-1100$ & $1320(260)$ & 7.3 \\
\hline ANZ & Ceppo Morelli & Western Alps & $45^{\circ} 58^{\prime}$ & $8^{\circ} 04^{\prime}$ & $800-1000$ & $1240(300)$ & 5.2 \\
\hline BOG & S. Bernardo & Western Alps & $46^{\circ} 09^{\prime}$ & $8^{\circ} 12^{\prime}$ & $1500-1700$ & $1250(346)$ & 6.0 \\
\hline TOC & Bosco della Colma & Western Alps & $46^{\circ} 09^{\prime}$ & $8^{\circ} 28^{\prime}$ & $1100-1300$ & $1610(420)$ & 7.2 \\
\hline VAR & Vargno & Western Alps & $45^{\circ} 39^{\prime}$ & $7^{\circ} 54^{\prime}$ & $1400-1700$ & $780(120)$ & 5.4 \\
\hline CRX & Croix de la Fana & Western Alps & $45^{\circ} 47^{\prime}$ & $7^{\circ} 25^{\prime}$ & $1700-2000$ & $670(100)$ & 5.8 \\
\hline BON & Bondinaz & Western Alps & $45^{\circ} 43^{\prime}$ & $7^{\circ} 23^{\prime}$ & $1100-1500$ & $690(110)$ & 6.1 \\
\hline PEN & Pendine & Western Alps & $45^{\circ} 42^{\prime}$ & $7^{\circ} 17^{\prime}$ & $950-1450$ & $700(120)$ & 6.7 \\
\hline $\mathrm{CHA}$ & Chabodey & Western Alps & $45^{\circ} 44^{\prime}$ & $7^{\circ} 03^{\prime}$ & $1000-1400$ & $890(170)$ & 6.2 \\
\hline BEL & Bellouque & Western Alps & $45^{\circ} 49^{\prime}$ & $7^{\circ} 21^{\prime}$ & $1000-1700$ & $970(190)$ & 5.6 \\
\hline GRE & Gressoney & Western Alps & $45^{\circ} 50^{\prime}$ & $7^{\circ} 49^{\prime}$ & $1400-1900$ & $810(210)$ & 6.1 \\
\hline BAG & Camaluf & Central Alps & $45^{\circ} 51^{\prime}$ & $10^{\circ} 26^{\prime}$ & $1200-1400$ & $1340(370)$ & 6.8 \\
\hline ALB & Albaredo & Central Alps & $46^{\circ} 05^{\prime}$ & $9^{\circ} 37^{\prime}$ & $1000-1300$ & $1230(220)$ & 6.9 \\
\hline AND & Paganella & Central Alps & $46^{\circ} 09^{\prime}$ & $11^{\circ} 00^{\prime}$ & $1000-1200$ & $1080(270)$ & 4.8 \\
\hline VPT & Fleres & Eastern Alps & $46^{\circ} 58^{\prime}$ & $11^{\circ} 21^{\prime}$ & $1300-1600$ & $670(220)$ & 5.1 \\
\hline LAU & Laudes & Eastern Alps & $46^{\circ} 41^{\prime}$ & $10^{\circ} 32^{\prime}$ & $1100-1400$ & $690(210)$ & 5.3 \\
\hline TRO & Trodena & Eastern Alps & $46^{\circ} 19^{\prime}$ & $11^{\circ} 22^{\prime}$ & $1200-1500$ & $1100(180)$ & 6.9 \\
\hline FAV & Favogna & Eastern Alps & $46^{\circ} 17^{\prime}$ & $11^{\circ} 11^{\prime}$ & $1200-1500$ & $730(220)$ & 7.1 \\
\hline SCA & S. Candido & Eastern Alps & $46^{\circ} 43^{\prime}$ & $12^{\circ} 16^{\prime}$ & $1300-1600$ & $770(260)$ & 4.7 \\
\hline TES & Tesimo & Eastern Alps & $46^{\circ} 32^{\prime}$ & $11^{\circ} 10^{\prime}$ & $1000-1300$ & $720(240)$ & 7.8 \\
\hline VIS & Val Visdende & Eastern Alps & $46^{\circ} 37^{\prime}$ & $12^{\circ} 39^{\prime}$ & $1400-1600$ & $920(260)$ & 5.2 \\
\hline DOS & Dosso & Eastern Alps & $45^{\circ} 55^{\prime}$ & $11^{\circ} 30^{\prime}$ & $1300-1500$ & $1430(320)$ & 5.9 \\
\hline PAU & Paularo & Eastern Alps & $46^{\circ} 32^{\prime}$ & $13^{\circ} 07^{\prime}$ & $900-1100$ & $1850(450)$ & 7.0 \\
\hline MNR & Monte Nero & Northern Apennines & $44^{\circ} 34^{\prime}$ & $9^{\circ} 30^{\prime}$ & $1400-1600$ & $1320(218)$ & 8.8 \\
\hline VEN & Ventasso & Northern Apennines & $44^{\circ} 23^{\prime}$ & $10^{\circ} 16^{\prime}$ & $1100-1300$ & $1400(250)$ & 8.4 \\
\hline APU & Alpi Apuane & Northern Apennines & $44^{\circ} 09^{\prime}$ & $10^{\circ} 26^{\prime}$ & $900-1200$ & $1790(370)$ & 10.3 \\
\hline $\mathrm{ABE}$ & Abetone & Northern Apennines & $44^{\circ} 09^{\prime}$ & $10^{\circ} 40^{\prime}$ & $1200-1400$ & $2540(470)$ & 7.2 \\
\hline VER & Foreste Casentinesi & Northern Apennines & $43^{\circ} 42^{\prime}$ & $11^{\circ} 56^{\prime}$ & $1100-1300$ & $1620(320)$ & 8.6 \\
\hline RTR & Bocca Trabaria & Central Apennines & $43^{\circ} 34^{\prime}$ & $12^{\circ} 11^{\prime}$ & $800-1100$ & $1320(260)$ & 10.7 \\
\hline PIG & Monte Amiata & Central Apennines & $42^{\circ} 53^{\prime}$ & $11^{\circ} 38^{\prime}$ & $1500-1700$ & $1330(320)$ & 8.7 \\
\hline MAC & Macera della Morte & Central Apennines & $42^{\circ} 44^{\prime}$ & $13^{\circ} 24^{\prime}$ & $900-1200$ & $1480(320)$ & 9.8 \\
\hline FVP & Fonte Volpona & Central Apennines & $41^{\circ} 53^{\prime}$ & $14^{\circ} 21^{\prime}$ & $800-1000$ & $1230(210)$ & 10.4 \\
\hline VAC & Vaccarizzo & Southern Apennines & $40^{\circ} 09^{\prime}$ & $16^{\circ} 05^{\prime}$ & $700-1000$ & $1030(320)$ & 10.2 \\
\hline GAR & Gariglione & Southern Apennines & $39^{\circ} 08^{\prime}$ & $16^{\circ} 39^{\prime}$ & $1500-1600$ & $2140(410)$ & 10.3 \\
\hline ARC & Archiforo & Southern Apennines & $38^{\circ} 33^{\prime}$ & $16^{\circ} 21^{\prime}$ & $1000-1200$ & $2020(390)$ & 10.7 \\
\hline
\end{tabular}

be native, although some silver fir planting has been carried out in the past, especially in the northern Apennines. In particular, the populations sampled in MNR (Piovani et al., 2010), APU (Amorfini et al., 2004) and VER (Piovani et al., 2010; Ducci \& Proietti, 1997) have been shown to have evolved naturally; in any case, only trees old enough ( $>80$ years) to have been in place prior to any recent afforestation activity were sampled. The populations from GOU, GOR, CHI, SAL, GBR, VIS, DOS, PAU, VER, ABE, FVP, ARC and GAR have been registered in the Italian National Book of Seed Stands: they were selected on basis of their phenotype and their health status (Morandini \& Magini, 1975; Ducci \& De Rogatis, 2010). The BAL, TOC, ALB and TRO populations are also "registered seed stands", although only at the regional level (Camerano et al., 2012). Most of the populations occur as mixed stands, accompanied by Norway spruce (Picea abies) and European larch
(Larix decidua) in the western and central Alps, Norway spruce and black pine (Pinus nigra) in the eastern Alps, and the European beech (Fagus sylvatica) in the Apennines. With one exception, each populations was represented by 24 adult, non-contiguous trees, selected at random. The exception was the APU population, where the samples comprised only 17 trees. The overall number of trees subjected to genotyping was 1,073 .

\section{Marker analysis}

Needles were stored at $-20^{\circ} \mathrm{C}$ until processed for DNA extraction. A $100 \mathrm{mg}$ batch of needles of each entry was treated with an E.Z.N.A. HP Plant DNA Mini kit (Omega Bio-tek Inc., Norcross, GA, USA), following the manufacturer's instructions. The resulting DNA templates were amplified using seven pairs of primers, each targeting a variable 
Table 2. Experimental details of the seven microsatellite loci assayed. A: mean number of alleles per population; $\mathrm{N}_{\mathrm{e}}:$ mean effective number of alleles per populations; I = Shannon's information index; $\mathrm{H}_{\mathrm{o}}$ : mean observed heterozygosity; $\mathrm{H}_{\mathrm{e}}$ : mean expected heterozygosity

\begin{tabular}{|c|c|c|c|c|c|c|c|c|c|c|}
\hline Locus & Repeat motif & $\begin{array}{l}\text { Forward and reverse primer } \\
\text { sequences } \\
\qquad\left(5^{\prime} \rightarrow 3^{\prime}\right)\end{array}$ & $\begin{array}{l}\text { Fluo- } \\
\text { rescent } \\
\text { label }\end{array}$ & $\begin{array}{l}\text { Total } \\
\text { num- } \\
\text { ber of } \\
\text { alleles }\end{array}$ & $\begin{array}{l}\text { Mo- } \\
\text { lecular } \\
\text { weight } \\
\text { range } \\
\text { (bp) }\end{array}$ & A & $\mathrm{N}_{\mathrm{e}}$ & I & $\mathrm{H}_{\mathrm{o}}$ & $\mathrm{H}_{\mathrm{e}}$ \\
\hline SF1 & $(\mathrm{CCG})_{9}$ & $\begin{array}{l}\text { TTGACGTGATTAACAATCCA } \\
\text { AAGAACGACACCATTCTCAC }\end{array}$ & IRD-700 & 10 & $202-229$ & 3.6 & 2.2 & 0.930 & 0.583 & 0.543 \\
\hline SFb4 & $(\mathrm{GT})_{16}$ & $\begin{array}{l}\text { GCCTTTGCAACATAATTGG } \\
\text { TCACAATTGTTATGTGTGTGG }\end{array}$ & IRD-800 & 26 & $144-200$ & 11.8 & 6.5 & 2.094 & 0.695 & 0.833 \\
\hline SFb5 & $(\mathrm{CT})_{15}$ & $\begin{array}{l}\text { AAAAAGCATCACTTTTCTCG } \\
\text { AAGAGGAGGGGAGTTACAAG }\end{array}$ & IRD-700 & 12 & 135-159 & 7.5 & 4.1 & 1.594 & 0.560 & 0.728 \\
\hline SFg6 & $(\mathrm{AC})_{9}$ & $\begin{array}{l}\text { GTAACAATAAAAGGAAGCTACG } \\
\text { TGTGACACATTGGACACC }\end{array}$ & IRD-800 & 7 & $102-116$ & 4.7 & 3.2 & 1.271 & 0.214 & 0.665 \\
\hline SF78 & $(\mathrm{CGCA})_{8}(\mathrm{CA})_{15} \mathrm{G}(\mathrm{CA})_{8}$ & $\begin{array}{l}\text { CATTGTTGTCTTTGTTTCACA } \\
\text { TGCACCGTTTTGTTTTTCC }\end{array}$ & IRD-700 & 51 & $145-263$ & 14.5 & 8.8 & 2.352 & 0.828 & 0.872 \\
\hline SF324 & $(\mathrm{CCG})_{8}$ & $\begin{array}{l}\text { TTTGAACGGAAATCAAATTCC } \\
\text { AAGAACGACACCATTCTCAC }\end{array}$ & IRD-800 & 12 & $94-154$ & 3.6 & 2.3 & 0.934 & 0.521 & 0.550 \\
\hline SF333 & $(\mathrm{CA})_{12}(\mathrm{TA})_{4}$ & $\begin{array}{l}\text { ATTTGTTCATTTTGGTCCTG } \\
\text { ACACAGGAAAAAGTCGGTAA }\end{array}$ & IRD-800 & 13 & $150-180$ & 6.4 & 4.1 & 1.551 & 0.528 & 0.743 \\
\hline
\end{tabular}

microsatellite locus (Cremer et al., 2006): SF1, SFb4, SFb5, SFg6, SF78, SF324, SF333 (Table 2).

For six of the seven microsatellites (the exception was SF333), each $13 \mu \mathrm{L}$ PCR, made up in 1x Promega (Madison, WI, USA) buffer, contained $2.5 \mathrm{mM} \mathrm{MgCl}_{2}$, $0.65 \mathrm{U}$ Taq polymerase (Promega), $0.5 \mu \mathrm{M}$ of each primer, $0.2 \mathrm{mM}$ dNTP and $\sim 20 \mathrm{ng}$ template DNA. For the SF333 assay, the $\mathrm{MgCl}_{2}$ concentration was reduced to $0.5 \mathrm{mM}$ and the primer concentration to 0.4 $\mu \mathrm{M}$. For the six assays excluding SF333, a touchdown amplification protocol was applied, which comprised an initial denaturation of $94^{\circ} \mathrm{C} / 5 \mathrm{~min}$, followed by ten cycles $\left(94^{\circ} \mathrm{C} / 30 \mathrm{~s}, 65^{\circ} \mathrm{C} / 30 \mathrm{~s}\right.$ reducing by $1^{\circ} \mathrm{C}$ per cycle, $72^{\circ} \mathrm{C} / 40 \mathrm{~s}$ ), a further 23 cycles of $94^{\circ} \mathrm{C} / 30 \mathrm{~s}$, $55^{\circ} \mathrm{C} / 50 \mathrm{~s}, 72^{\circ} \mathrm{C} / 40 \mathrm{~s}$ and a final extension of $72^{\circ} \mathrm{C} / 7$ min. For the SF333 assay, the initial denaturation was $94^{\circ} \mathrm{C} / 3 \mathrm{~min}$, and this was followed by 30 cycles of $94^{\circ} \mathrm{C} / 30 \mathrm{~s}, 50^{\circ} \mathrm{C} / 30 \mathrm{~s}, 65^{\circ} \mathrm{C} / 90 \mathrm{~s}$, and a final extension of $65^{\circ} \mathrm{C} / 15 \mathrm{~min}$. The forward primers were fluorescently 5 ' labelled with either IRD-700 or IRD800. The resulting amplicons were electrophoresed through a denaturing $6 \%$ polyacrylamide gel and detected automatically using a DNA 4200 Sequencer (LI-COR Biotechnology, Lincoln, NE, USA). The gels were run for $2 \mathrm{~h}$ at a constant $2,000 \mathrm{~V}$ in $1 \mathrm{x}$ TBE buffer. IRD 700- and IRD 800-labelled ladders were included to enable the estimation of fragment sizes.

\section{Data analysis}

Genetic variation within populations averaged over the seven loci was estimated using GenAlEx v. 6 software (Peakall \& Smouse, 2006, 2012), which also allowed for the calculation of allele frequencies, the mean number of alleles per locus, the mean number of private and effective alleles per locus, along with the observed and expected heterozygosity level $\left(\mathrm{H}_{\mathrm{o}}\right.$ and $\mathrm{H}_{\mathrm{e}}$ respectively). Allelic richness was derived using FStat software (Goudet, 1995). Genotypic disequilibrium between pairs of loci was tested at the single population level and across all populations, with Fisher's exact test using Arlequin software (Excoffier et al., 2005). Fisher's exact test based on the Markov Chain algorithm (Guo \& Thompson, 1992) was used to detect deviations from Hardy-Weinberg equilibrium for each population and each locus. Where a significant deficiency of heterozygotes was detected, the presence of a null alleles was inferred (Pemberton et al., 1995). Loci showing a high frequencies of null alleles were identified using Micro-Checker software (Van Oosterhout et al., 2004). The estimation of the inbreeding coefficients took into account the frequency of null alleles; the necessary calculations were performed with INEst software (Chybicki \& Burczyk, 2009), selecting the individual inbreeding model (IIM) with a Gibbs sampler of $10^{5}$ iterations (Chybicki \& Burczyk, 2009). The Bottleneck v.1.2.02 program (Piry et al., 1999) was employed to predict recent population bottlenecks. A Wilcoxon's sign rank test compared the level of heterozygosity expected assuming a Hardy-Weinberg equilibrium with predicted heterozygosity at mutation-drift equilibrium, on the basis of the observed allele number (Piry et al., 1999). The program was run both assuming a two-phase model (TPM) of mutation, and a pure stepwise or infinite allele models (SMM, Di Rienzo et al., 1994). A thousand simulations were performed for each sample, consisting of $90 \%$ single mutations and $10 \%$ multistep alterations. FreeNA (Chapuis \& Estoup, 2007) was used to compute the Weir (1996) F-statistics; $\mathrm{F}_{\mathrm{ST}}$ was taken as an estimate of the proportion of the overall genetic variance contributed 
by the between population component (Slatkin, 1995). The Phylip package (Felsenstein, 2013) used the resulting genetic distance matrix to construct a UPGMA-based dendrogram. A cophenetic value matrix was then calculated by the Coph routine within Ntsys-pc software (Rholf, 2006); this was used by the Mxcomp routine to evaluate the goodness-of-fit of the predicted clusters. An analysis of molecular variance (AMOVA; Excoffier et al., 1992) was performed using the Arlequin package (Excoffier et al., 2005). The genetic structure of the populations was obtained by deploying the Pritchard et al. (2000) Structure program, setting a burn-in period of $10^{5}$ followed by $5 \times 10^{5}$ iterations, and using both the admixture ancestry and the correlated allele frequency model. $\mathrm{K}$ values were calculated from a mean of 20 runs for each value of $\mathrm{K}$ between 1 and 10. The optimum value of $\mathrm{K}$ was determined following Rosenberg et al. (2001) and Evanno et al. (2005).

\section{Results}

\section{Allelic diversity and within population genetic variation}

A summary of the within population genetic diversity statistics is shown as Table 3. A total of 131 alleles (size range 94-263 bp) were revealed at the seven microsatellite loci, representing a mean of about 19 per locus. The most variable locus was SF78 (51 alleles) and the least variable SFg6 (seven alleles). In total, 16 of the alleles were "private" (i.e., present in only a single population); on a per locus basis, their number ranged from zero (SFb5) to six (SF78). The FVP and GAR populations each harboured two, and the 12 populations NAV, GOR, GRB, BOG, TOC, VPT, SCA, TES, DOS, APU, MAC and ARC each harboured one private allele. On average, at least seven alleles per locus were present in all 45 populations; the lowest number occurred in the APU population, but even here, allele richness and the levels of heterozygosity lay close to the global means. Populations collected from the Alps were the least variable (Fig. 2, Table 3): this was particularly evident for populations derived from the north-western sector. The global $\mathrm{H}_{\mathrm{e}}$ was 0.724 , while $\mathrm{H}_{\mathrm{o}}$ was only 0.563 : this difference likely reflected a combination of non-random mating and the presence of null alleles. The latter were present at significant frequency with respect to both SFg6 (average frequency 0.14) and SFb5 (0.05). Re-calculating the inbreeding coefficients following adjustment for the frequency of null alleles considerably reduced the extent of the deviation from the Hardy-Weinberg equilibrium $\left(\mathrm{F}_{\mathrm{IS}}\right.$ ranged from 0.013 in $\mathrm{ABE}$ to 0.080 in

Table 3. Within population measures of genetic variation. A: mean number of alleles per locus; Ne: effective number of alleles per locus; Ar10: allele richness; Pa: frequency of private alleles per locus; $\mathrm{H}_{\mathrm{o}}$ : mean observed heterozygosity; $\mathrm{H}_{\mathrm{e}}$ : mean expected heterozygosity; $\mathrm{F}_{\mathrm{IS}}$ : mean inbreeding coefficient, taking into account null alleles. None of the $\mathrm{F}_{\mathrm{IS}}$ values are significantly different from zero. Values in parenthesis for overall means are standard errors. BTPM and BSMM: Wilcoxon test parameters regarding evidence for recent bottlenecks; the former is derived from the two-phase model of mutation (TPM), and the latter from the pure stepwise or infinite allele model (SMM). ns: not significant, * **: significant at $\mathrm{p}<0.05,<0.01$

\begin{tabular}{lccccccccc}
\hline \multicolumn{1}{c}{ Population } & $\mathrm{A}$ & $\mathrm{N}_{e}$ & $\mathrm{~A}_{\text {r10 }}$ & $\mathrm{P}_{a}$ & $\mathrm{H}_{o}$ & $\mathrm{H}_{e}$ & $\mathrm{~F}_{\text {IS }}$ & $\mathrm{B}_{\text {TPM }}$ & $\mathrm{B}_{\text {SMM }}$ \\
\hline GOU & 7.4 & 4.4 & 4.336 & 0 & 0.565 & 0.688 & 0.031 & $\mathrm{~ns}$ & $\mathrm{~ns}$ \\
NAV & 7.6 & 4.0 & 4.371 & 0.143 & 0.621 & 0.722 & 0.015 & $\mathrm{~ns}$ & $\mathrm{~ns}$ \\
GOR & 7.7 & 4.5 & 4.527 & 0.143 & 0.637 & 0.735 & 0.024 & $\mathrm{~ns}$ & $\mathrm{~ns}$ \\
VAL & 7.3 & 4.0 & 4.418 & 0 & 0.581 & 0.734 & 0.073 & $\mathrm{~ns}$ & $\mathrm{~ns}$ \\
BAL & 6.7 & 3.8 & 4.135 & 0 & 0.556 & 0.690 & 0.019 & $\mathrm{~ns}$ & $\mathrm{~ns}$ \\
CHI & 7.1 & 3.9 & 4.406 & 0 & 0.593 & 0.708 & 0.014 & $\mathrm{~ns}$ & $\mathrm{~ns}$ \\
SAL & 7.6 & 4.1 & 4.342 & 0 & 0.554 & 0.686 & 0.016 & $\mathrm{~ns}$ & $\mathrm{~ns}$ \\
GRB & 6.4 & 3.6 & 3.884 & 0.143 & 0.513 & 0.657 & 0.020 & $\mathrm{~ns}$ & $\mathrm{~ns}$ \\
FON & 6.6 & 4.0 & 4.342 & 0 & 0.497 & 0.727 & 0.024 & $\mathrm{~ns}$ & $\mathrm{~ns}$ \\
SES & 6.6 & 3.8 & 4.161 & 0 & 0.509 & 0.698 & 0.020 & $\mathrm{~ns}$ & $\mathrm{~ns}$ \\
CER & 6.6 & 3.7 & 4.084 & 0 & 0.560 & 0.700 & 0.021 & $\mathrm{~ns}$ & $\mathrm{~ns}$ \\
ANZ & 7.4 & 3.8 & 4.203 & 0 & 0.520 & 0.716 & 0.023 & $\mathrm{~ns}$ & $\mathrm{~ns}$ \\
BOG & 6.9 & 3.4 & 3.973 & 0.143 & 0.523 & 0.679 & 0.030 & $\mathrm{~ns}$ & $\mathrm{~ns}$ \\
TOC & 7.0 & 3.5 & 4.076 & 0.143 & 0.604 & 0.706 & 0.017 & $\mathrm{~ns}$ & $\mathrm{~ns}$ \\
VAR & 6.9 & 3.7 & 4.207 & 0 & 0.461 & 0.689 & 0.080 & $\mathrm{~ns}$ & $\mathrm{~ns}$ \\
CRX & 7.1 & 4.2 & 4.474 & 0 & 0.488 & 0.722 & 0.046 & $\mathrm{~ns}$ & $\mathrm{~ns}$ \\
BON & 6.3 & 4.0 & 4.275 & 0 & 0.488 & 0.732 & 0.051 & $\mathrm{~ns}$ & $\mathrm{~ns}$ \\
PEN & 7.0 & 3.9 & 4.234 & 0 & 0.462 & 0.683 & 0.037 & $\mathrm{~ns}$ & $\mathrm{~ns}$ \\
CHA & 7.7 & 4.1 & 4.524 & 0 & 0.502 & 0.722 & 0.055 & $\mathrm{~ns}$ & $\mathrm{~ns}$ \\
BEL & 5.9 & 3.0 & 3.772 & 0 & 0.450 & 0.649 & 0.065 & $\mathrm{~ns}$ & $\mathrm{~ns}$ \\
GRE & 6.6 & 3.9 & 4.132 & 0 & 0.492 & 0.680 & 0.032 & $\mathrm{~ns}$ & $\mathrm{~ns}$
\end{tabular}




\begin{tabular}{llllllcccc}
\hline \multicolumn{1}{c}{ Population } & $\mathrm{A}$ & $\mathrm{N}_{\mathrm{e}}$ & $\mathrm{A}_{\text {rlo }}$ & $\mathrm{P}_{\mathrm{a}}$ & $\mathrm{H}_{o}$ & $\mathrm{H}_{e}$ & $\mathrm{~F}_{\text {Is }}$ & $\mathrm{B}_{\text {IPM }}$ & $\mathrm{B}_{\text {SMM }}$ \\
\hline BAG & 7.0 & 3.9 & 4.290 & 0 & 0.578 & 0.712 & 0.040 & $\mathrm{~ns}$ & $\mathrm{~ns}$ \\
ALB & 7.9 & 4.2 & 4.405 & 0 & 0.569 & 0.715 & 0.022 & $\mathrm{~ns}$ & $\mathrm{~ns}$ \\
AND & 7.7 & 4.6 & 4.405 & 0 & 0.574 & 0.729 & 0.014 & $\mathrm{~ns}$ & $\mathrm{~ns}$ \\
VPT & 7.9 & 4.6 & 4.600 & 0.143 & 0.554 & 0.735 & 0.020 & $\mathrm{~ns}$ & $\mathrm{~ns}$ \\
LAU & 8.3 & 5.5 & 4.907 & 0 & 0.553 & 0.786 & 0.030 & $\mathrm{~ns}$ & $\mathrm{~ns}$ \\
TRO & 8.4 & 4.5 & 4.492 & 0 & 0.515 & 0.719 & 0.040 & $\mathrm{~ns}$ & $\mathrm{~ns}$ \\
FAV & 7.9 & 4.4 & 4.354 & 0 & 0.605 & 0.713 & 0.030 & $\mathrm{~ns}$ & $\mathrm{~ns}$ \\
SCA & 8.1 & 5.3 & 4.688 & 0.143 & 0.546 & 0.763 & 0.036 & $\mathrm{~ns}$ & $\mathrm{~ns}$ \\
TES & 8.6 & 4.5 & 4.592 & 0.143 & 0.517 & 0.731 & 0.033 & $\mathrm{~ns}$ & $\mathrm{~ns}$ \\
VIS & 8.3 & 4.7 & 4.481 & 0 & 0.499 & 0.732 & 0.029 & $\mathrm{~ns}$ & $\mathrm{~ns}$ \\
DOS & 7.9 & 4.5 & 4.461 & 0.143 & 0.555 & 0.720 & 0.041 & $\mathrm{~ns}$ & $\mathrm{~ns}$ \\
PAU & 7.9 & 4.7 & 4.396 & 0 & 0.568 & 0.709 & 0.017 & $\mathrm{~ns}$ & $\mathrm{~ns}$ \\
MNR & 6.9 & 4.6 & 4.602 & 0 & 0.593 & 0.760 & 0.051 & $*$ & $\mathrm{~ns}$ \\
VEN & 6.3 & 4.6 & 4.520 & 0 & 0.529 & 0.737 & 0.040 & $* *$ & $\mathrm{~ns}$ \\
APU & 5.1 & 3.8 & 4.333 & 0.143 & 0.539 & 0.707 & 0.035 & $\mathrm{~ns}$ & $\mathrm{~ns}$ \\
ABE & 8.1 & 6.0 & 5.011 & 0 & 0.673 & 0.774 & 0.013 & $* *$ & $* *$ \\
VER & 8.0 & 5.7 & 4.934 & 0 & 0.692 & 0.779 & 0.022 & $* *$ & $*$ \\
RTR & 8.3 & 4.6 & 4.495 & 0 & 0.645 & 0.725 & 0.016 & $\mathrm{~ns}$ & $\mathrm{~ns}$ \\
PIG & 8.4 & 6.5 & 5.139 & 0 & 0.636 & 0.778 & 0.022 & $* *$ & $* *$ \\
MAC & 8.4 & 5.8 & 4.984 & 0.143 & 0.615 & 0.762 & 0.021 & $*$ & $\mathrm{~ns}$ \\
FVP & 7.7 & 4.8 & 4.698 & 0.286 & 0.649 & 0.760 & 0.037 & $\mathrm{~ns}$ & $\mathrm{~ns}$ \\
VAC & 8.7 & 6.4 & 5.197 & 0 & 0.697 & 0.791 & 0.014 & $* *$ & $*$ \\
GAR & 8.3 & 5.8 & 4.942 & 0.286 & 0.532 & 0.753 & 0.029 & $\mathrm{~ns}$ & $\mathrm{~ns}$ \\
ARC & 9.0 & 5.4 & 4.990 & 0.143 & 0.709 & 0.768 & 0.014 & $\mathrm{~ns}$ & $\mathrm{~ns}$ \\
Overall mean & $7.45(0.24)$ & $4.47(0.15)$ & 4.453 & 0.046 & $0.563(0.012)$ & $0.724(0.008)$ & $0.030(0.016)$ & \\
\hline & & & & & & & & & \\
\hline
\end{tabular}

VAR, with a mean of 0.030). Since the confidence intervals calculated by INEst software overlapped zero in every population, it was concluded that none of the $\mathrm{F}_{\mathrm{IS}}$ values were significantly different from zero. Although for most of the populations the $\mathrm{H}_{\mathrm{e}}$ value and the gene diversity at mutation-drift equilibrium

\section{a) Expected heterozygosity}

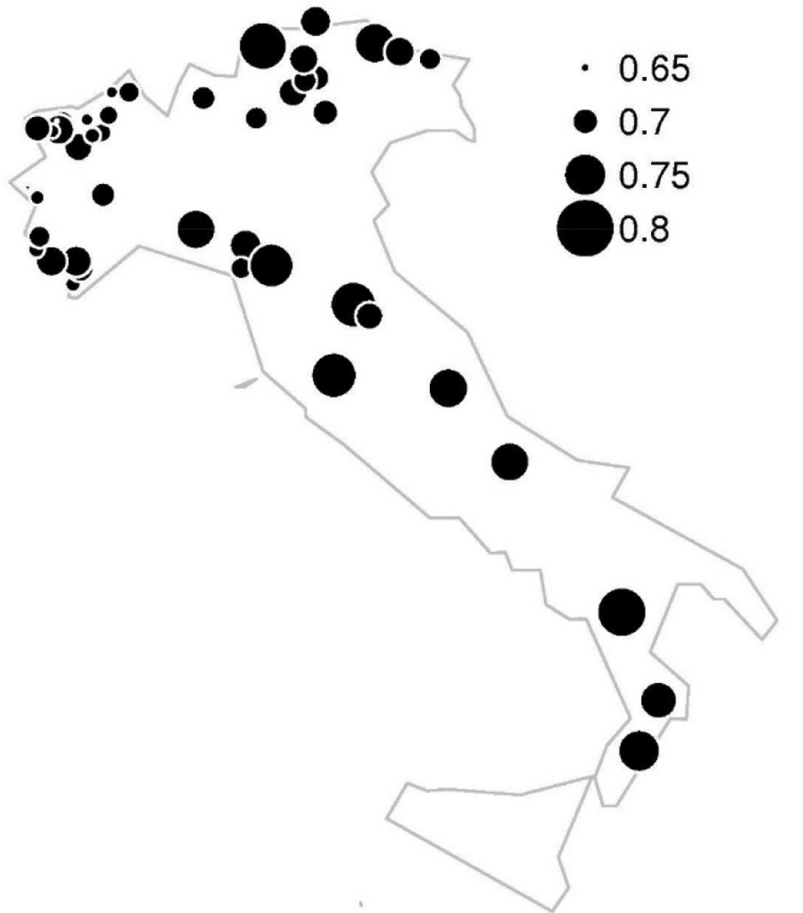

b) Allelic richness

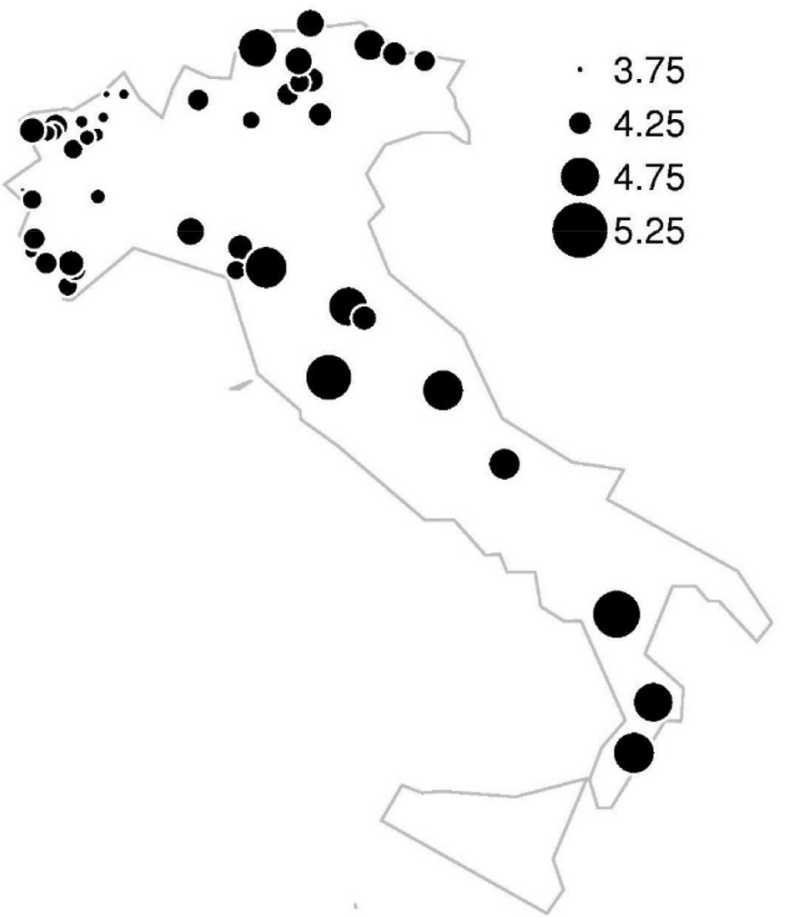

Fig. 2. Genetic variation in Italian silver fir populations. (a) Expected heterozygosity $\left(\mathrm{H}_{\mathrm{e}}\right)$, (b) allele richness 
did not differ significantly from one another, some evidence for recent bottlenecks was revealed in populations sampled from the central and southern parts of the Apennines (MNR, VEN, ABE, VER, PIG, MAC and VAC: see Table 3 ).

\section{Genetic differentiation between populations}

Most of the genetic diversity was partitioned to the within population component $\left(\mathrm{F}_{\mathrm{ST}}\right.$ of 0.082 , SE $0.005)$. The AMOVA confirmed this conclusion, revealing that $8.25 \%$ of the variance was assignable to differences among populations, leaving the remaining $91.75 \%$ to the within population component (data not shown). The $\mathrm{F}_{\mathrm{ST}}$ values on a per locus basis ranged from 0.060 (SF333) to 0.107 (SFg6). When the extent of genetic divergence between populations was quantified using the pairwise $\mathrm{F}_{\mathrm{ST}}$ matrix, the $\mathrm{F}_{\mathrm{ST}}$ values were found to lie between 0.009 (BOG and ANZ) and 0.108 (CHA and APU). Almost all of the pairwise $\mathrm{F}_{S T}$ values lay significantly above zero, suggesting the presence of a distinct population structure (data not shown). The UPGMA-based phylogenetic analysis (Fig. 3) confirmed a level of between population differentiation, as well as a consistent degree of structuring. The cophenetic correlation coefficient was 0.807 ( $\mathrm{P}<0.001)$, implying a high goodness-of-fit for the cluster analysis. In particular, the populations sampled from the central and eastern Alps displayed a clear tendency to cluster (CEAl in Fig. 3), while the Apennine populations were split into two groups, one (NAp) including most of the

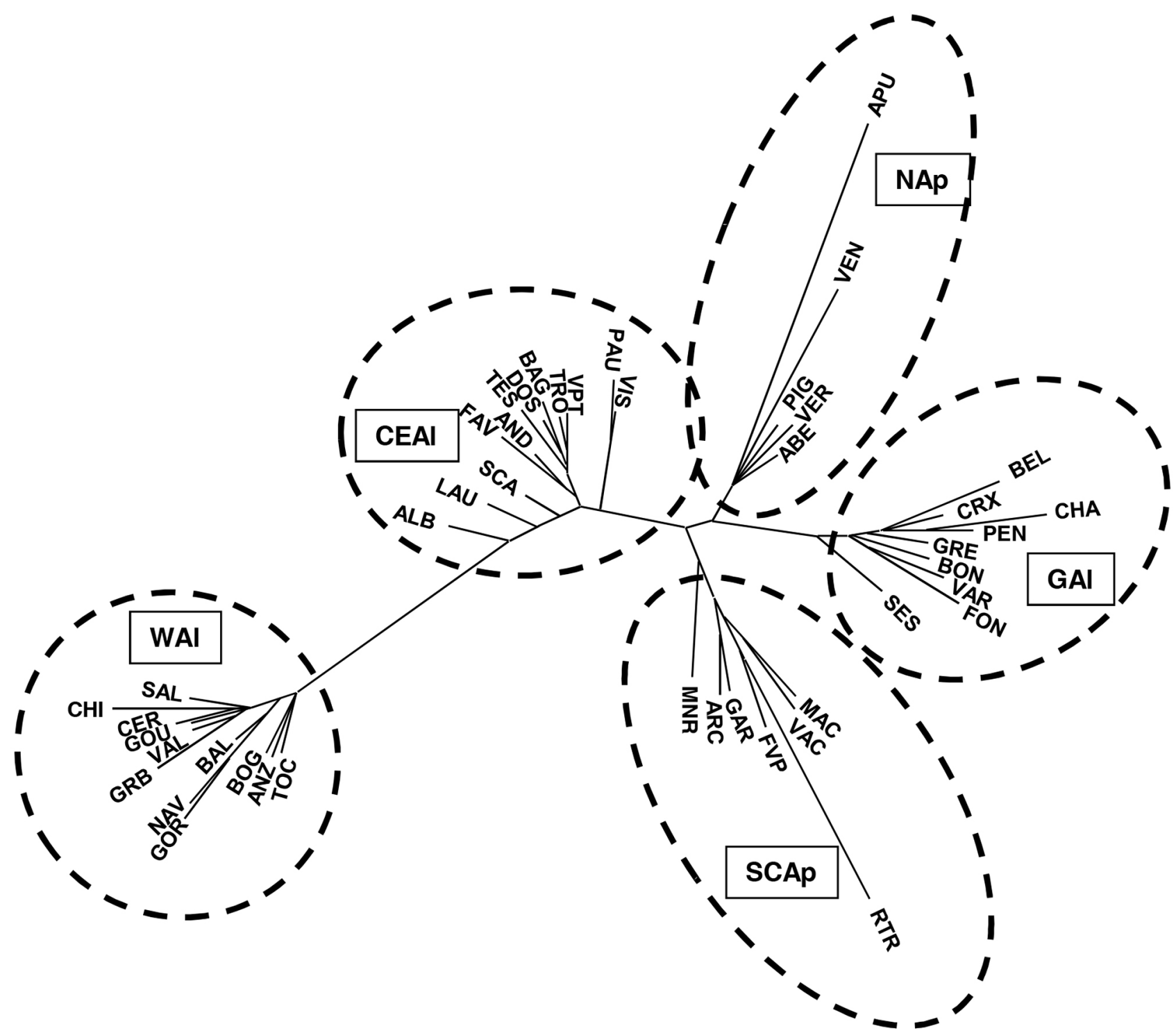

Fig. 3. Genetic structure of the Italian silver fir populations. Dotted lines link populations from a shared geographical region: WAl (western Alps), CEAl (central and eastern Alps), NAp (northern Apennines), GAl (Graian Alps), SCAp (central and southern Apennines) 


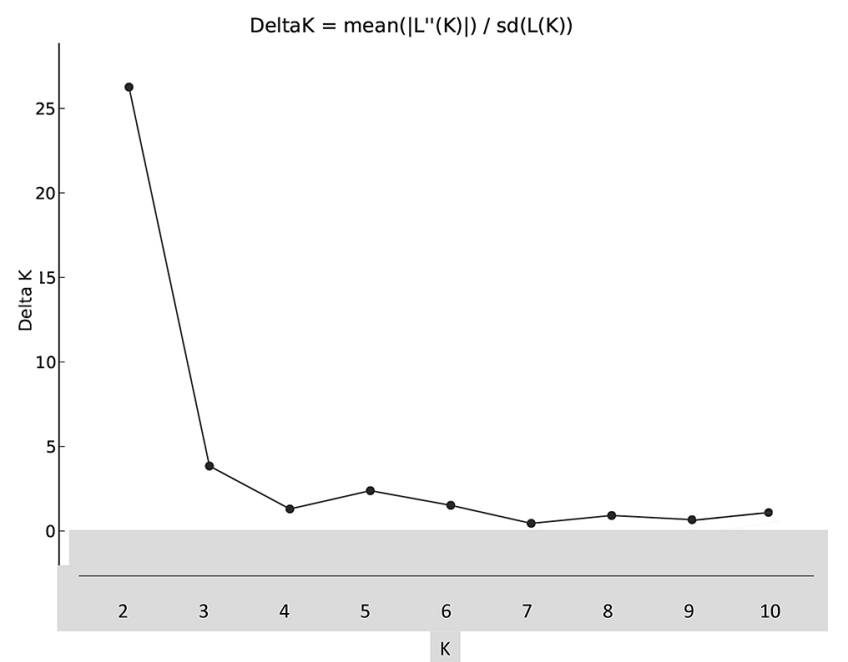

Fig. 4. Identification of the most likely number of clusters formed by 45 populations of silver fir in Italy

populations sampled from the northern part of the range together with PIG (central Apennines, but strongly isolated by others), while the other (SCAp) combined the populations sampled from the central and southern part with one sampled from the northern Apennines (MNR). The populations sampled from the western Alps also formed two clusters, one comprising the trees growing around the Aosta Valley (GAl) and the other those growing in the Ligurian, Maritime, Cottian and Pennine Alps (WAl). The Structure analysis implied that a K value of 2 was the most likely (Fig. 4). Most of the trees sampled from the north-western populations belonged to cluster 1, whereas those sampled from the eastern Alps and the Apennines were dominated by individuals belonging to cluster 2 (Fig. 5). Some admixed populations were detected among most of the geographical regions, although admixture was prominent in the GAl populations (FON, SES, VAR, CRX, BON, PEN, CHA, BEL and GRE).

\section{Discussion}

The objective of this research was to assess the level and the distribution of genetic variability of natural stands of silver fir in Italy, with a view to elaborate a rational strategy for conserving its genetic diversity. The genotyping of samples of the 45 populations, albeit at only a limited number of nuclear microsatellite loci, revealed an extensive bank of allelic variation: the mean number of alleles per locus was as high as 9.0 (mean 7.4), while $\mathrm{H}_{\mathrm{e}}$ ranged from
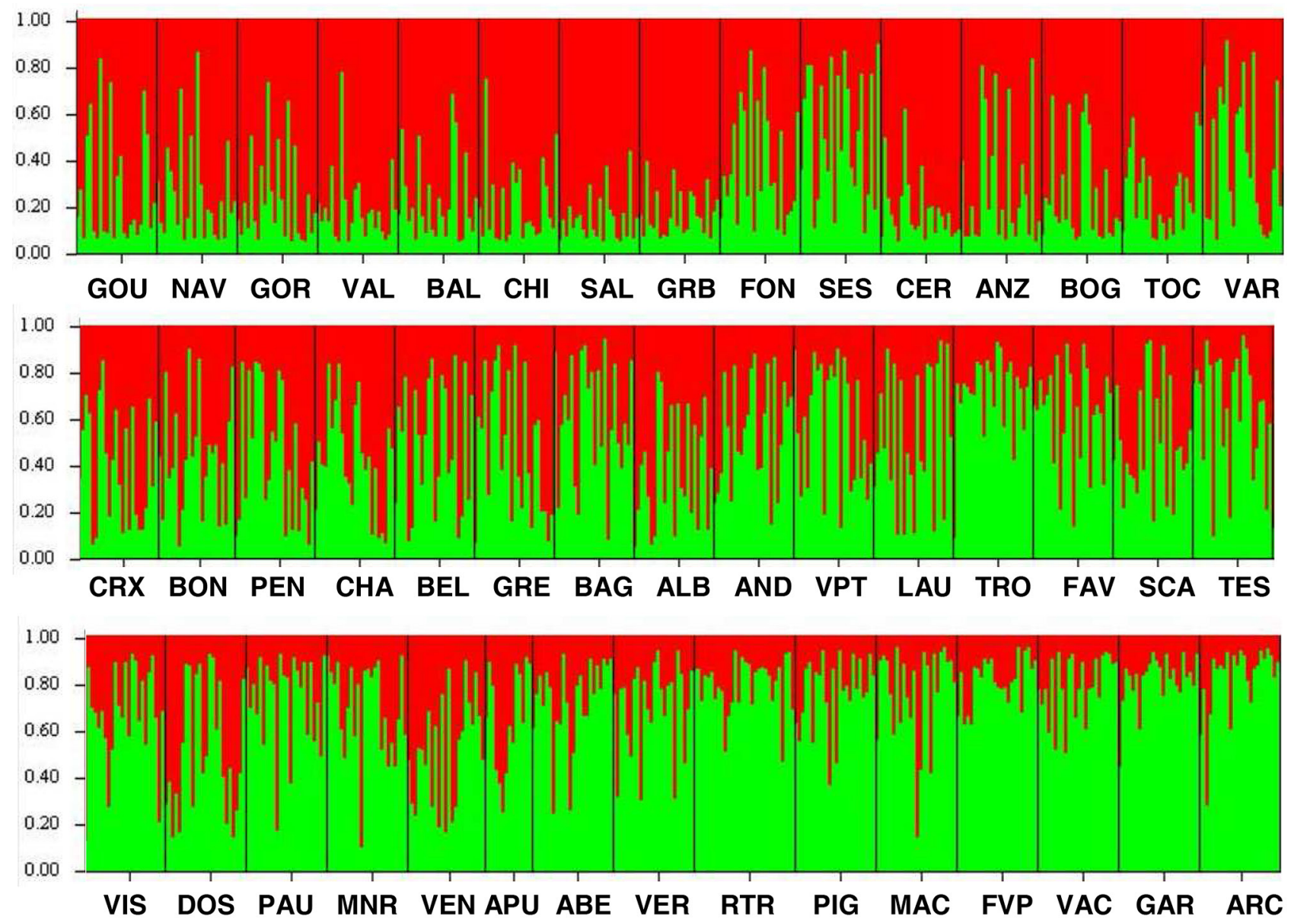

Fig. 5. Inference of population structure in silver fir using STRUCTURE software $(K=2)$ 
0.649 to 0.791 (mean 0.723) (Fig. 2 and Table 3). The presence of high diversity was not unexpected, since it is a feature of many woody plants, especially those which are not specialized to a narrow habitat (Hamrick et al., 1992). The genetic diversity present in the populations growing in the Apennine sites (especially in the central and southern part of the range) was higher than that of the Alpine ones; with respect to the latter, those sourced from the eastern part of the range tended to be more variable than those from the western part. An exception was found among populations sampled in the far south-western region (Ligurian and Maritime Alps: GOU, NAV, GOR and VAL), where genetic variability was close to the global mean. High levels of genetic variability in this area have been reported previously for a number of species (Minuto et al., 2006; Ferrazzini et al., 2007; Casazza et al., 2016), implying that this region has a rather unique ecology, reflecting the presence of very high mountains (up to 3,297 $\mathrm{m}$ a.s.l. of Argentera $\mathrm{Mt}$ ) in close proximity to the Mediterranean Sea (maximum distance $50 \mathrm{~km}$ ) (Casazza et al., 2008). The area is considered as an important biodiversity hot-spot (Medail \& Quezel, 1999). A further indication of the greater variability of the Apennine populations was the high frequency of private alleles. Some evidence for recent population bottlenecks was associated with some of the sites along the Apennine chain (Table 3); the most probable cause of this was the widespread logging carried out in the area over the last 200 years. Genetic drift is expected to have been an issue only in populations experiencing fragmentation and isolation (e.g., MNR and VEN).

The overall level of between population diversity was comparatively high $\left(\mathrm{F}_{\mathrm{ST}} \mathrm{0.082}\right)$, especially given the small size of the study area, and also confirmed by AMOVA. Conifer populations are typically associated with rather low levels of genetic differentiation, thanks to their allogamous mating system and their efficient dispersal systems for both pollen and seed (Petit \& Hampe, 2006; Piotti et al., 2009; Williams, 2010). Still, a powerful enough environment-driven selection pressure can generate local adaptation even where gene flow is high, as exemplified in Abies alba by Mosca et al. (2012).

The Graian Alps, which include the Aosta Valley and neighbouring valleys, were highly differentiated from the other alpine populations, even though the physical distance involved are small (particularly for the Cottian and Pennine Alps). This could be due to the specific features of this area, which is bordered to the west and north by the highest mountains in the entire Alpine chain (Mont Blanc and Monte Rosa in particular); these represent a very effective barrier against gene flow. At the southern end of the Aosta Valley is a large area where silver fir is rare or even absent, which again likely constitutes a major obstacle to gene flow. The possibility is that the species entered Aosta Valley during postglacial period, but became isolated from the other lineages that diffused and evolved, by adaptation, at a faster rate. A similar scenario has been proposed for other species by Schönswetter et al. (2005), Bettin et al. (2007) and Thiel-Egenter et al. (2010).

For practical reasons, the number of trees analysed per population was limited to 24 , which raises the possibility of sampling bias. Although the precision of any estimate of genetic variability can clearly be improved by increasing the sample size, $\mathrm{F}_{\mathrm{ST}}$ is known to be associated with only a minor sampling variance at multi-allelic loci such as microsatellites (Kalinowski, 2005). Similarly, more precision can generally be obtained by assaying a greater number of loci than by increasing the number of individuals genotyped (Kalinowski, 2005). Both the genetic markers (highly polymorphic microsatellites) and the population genetic indices $\left(\mathrm{F}_{\mathrm{ST}}\right)$ applied were directed at minimizing estimation biases caused by a small sample size (Miyamoto et al., 2008). With this proviso, the genetic architecture of the silver fir stands in the southern part of the Apennine range implied that the region represented a refugium during the last Pleistocene glaciation, leaving behind a number of well differentiated and isolated populations harbouring a considerable level of genetic variability. The occurrence of such high levels of genetic variability appears at odds with the norm for marginal populations, usually small and which tend to become highly adapted to a specific ecological niche and suffer from genetic erosion (Fady et al., 2016). However, this seems not the case of silver fir in southern Italy, probably because the large size of the populations and the presence of very favourable climatic conditions, as already observed in previous studies (Longauer et al., 2003)

The implication of the isolation of the populations growing in southern Apennine range is that the postglacial expansion of silver fir into central and northern Europe most probably originated from the northern Apennines, as suggested by Muller et al. (2007). Other species appear to have behaved in a similar way (Feliner, 2011). An important conclusion to be drawn is that silver fir genetic resources need to be preserved throughout the Apennines. The point of discontinuity between the non-migrating southern Apennine populations and the migrating northern ones remains undefined. The present data suggest that this demarcation lies between Tuscany/ Emilia-Romagna and Umbria/Marche, but this conclusion is at best provisional. The PIG population is rather exceptional in this context: although it lies within the Northern Apennines area, it is very isolated, and represents a population in which the evidence for genetic bottleneck is strongest; nevertheless, its 
level of diversity was higher than the global mean, in contrast to some of other small, isolated populations in the Northern Apennines zone, which showed clear symptoms of genetic erosion. The APU population is of particular conservation value, since despite its very small size (only a few tens of individuals), it harboured a number of private alleles and showed no evidence of any bottleneck. Valuable populations like this, as pointed out by Piovani et al. (2010), require careful management, which should include, for example, the cultivation of local seed. Overall, the diversity patterns revealed in the silver fir populations were consistent with the "rear edge versus leading edge" concept, which emphasizes the importance of peripheral populations for species survival and future adaptation to a changing environment (Hampe \& Petit, 2005).

Apart from contributing to the understanding of silver fir diversity, the conclusions reached here can be used to set in place an effective programme of species diversity preservation. According to the European Council Directive 1999/105/CE, forest reproductive material falling into the "source-identified" and "selected" categories should be used only within the same region of provenance. The identification of these "regions of provenance" therefore represents both a priority for the in situ conservation of this species and an important management task for the authorities responsible for afforestation.

\section{Acknowledgments}

This research was supported by grants made to the authors by the Piedmont and Aosta Valley regions and by Bolzano province. Our thanks are due to staff of the Regional Forest Services who facilitated the tree sampling.

\section{References}

Amorfini A, Bartelletti A, Cavalloni G, Genovesi G, Guazzi E, Piovani P \& Ronchieri I (2004) Studies and methods of nature conservation about a relict population of Abies alba Miller in the Apuan Alps Regional Park (Tuscany-Italy). International Symposium "Conception and methods of nature conservation in Europe", Cluj-Napoca (Romania), 16-19 September 2004.

Bettin O, Cornejo C, Edwards PJ \& Holderegger R (2007) Phylogeography of the high alpine plant Senecio halleri (Asteraceae) in the European Alps: in situ glacial survival with postglacial stepwise dispersal into peripheral areas. Molecular Ecology 16: 2517-2524.
Camerano P, Ferrazzini D, Ducci F \& Belletti P (2012) Regioni di Provenienza per l'abete bianco. Sherwood 182: 35-40.

Casazza G, Zappa E, Mariotti MG, Médail F \& Minuto L (2008) Ecological and historical factors affecting distribution pattern and richness of endemic plant species: the case of the Maritime and Ligurian Alps hotspot. Diversity and Distributions 14: 47-58.

Casazza G, Barberis G, Guerrina M, Zappa E, Mariotti M \& Minuto L (2016) The plant endemism in the Maritime and Ligurian Alps. Biogeographia - The Journal of Integrative Biogeogrpahy 31: 73-88.

Chapuis MP \& Estoup A (2007) Microsatellite null alleles and estimation of population differentiation. Molecular Biology and Evolution 24: 621631.

Cheddadi R, Birks JHB, Tarroso P, Liepelt S, Gömöry D, Dullinger S, Meier ES, Hülber K, Maiorano L \& Laborde H (2014) Revisiting tree-migration rates: Abies alba (Mill.), a case study. Vegetation History and Archaeobotany 23: 113-122.

Chybicki I \& Burczyk J (2009) Simultaneous estimation of null alleles and inbreeding coefficients. Journal of Heredity 100: 106-113.

Cremer E, Liepelt S, Sebastiani F, Buonamici A, Michalczyk IM, Ziegenhagen B \& Vendramin GG (2006) Identification and characterization of nuclear microsatellite loci in Abies alba Mill. Molecular Ecology Notes 6: 374-376.

Dering M, Sękiewicz K, Boratyńska K, Litkowiec M, Iszkuło G, Romo A \& Boratyński A (2014) Genetic diversity and inter-specific relations of western Mediterranean relic Abies taxa as compared to the Iberian A. alba. Flora 209: 367-374.

Di Rienzo A, Peterson AC, Garza JC, Valdes AM, Slatkin M \& Freimer NB (1994) Mutational processes of simple-sequence repeat loci in human populations. Proceedings of the National Academy of Science of the United States of America 91: 3166-3170.

Ducci F \& Proietti R (1997) Aspetti genetici delle risorse di abete bianco (Abies alba Mill.) nel comprensorio del Parco Nazionale delle Foreste Casentinesi. Annali Istituto Sperimentale Selvicoltura. Arezzo 28: 63-73.

Ducci F, Proietti R \& Favre JM (1998) Le genre Abies en Italie: écologie générale, gestion sylvicole et resources génétiques. Forêt Méditerranéenne 19: 153-164.

Ducci F \& De Rogatis A (2010) Risorse genetiche forestali in Italia. CRA SEL - Centro di Ricerca per la Selvicoltura, Arezzo.

Eckert CG, Samis KE \& Lougheed SC (2008) Genetic variation across species' ranges: the central-mar- 
ginal hypothesis and beyond. Molecular Ecology 17: 1170-1188.

Escudero A, Iriondo JM \& Torres ME (2003) Spatial analysis of genetic diversity as a tool for plant conservation. Biological Conservation 113: 351-365.

Evanno G, Regnaut S \& Goudet J (2005) Detecting the number of clusters of individuals using the software structure: a simulation study. Molecular Ecology 14: 2611-2620.

Excoffier L, Smouse PE \& Quattro JM (1992) Analysis of molecular variance inferred from metric distances among DNA haplotypes: application to human mitochondrial DNA restriction data. Genetics 131: 479-491.

Excoffier L, Laval G \& Schneider S (2005) Arlequin (version 3.0): An integrated software package for population genetics data analysis. Evolutionary Bioinformatics 1: 47-50.

Fady B, Aravanopoulos FA, Alizoti P, Mátyás C, von Wühlisch G, Westergren M, Belletti P, Cvjetkovic B, Ducci F, Huber G, Kelleher CT, Khaldi A, Dagher Kharrat MB, Kraigher H, Kramer K, Mühlethaler U, Peric S, Perry A, Rousi M, Sbay H, Stojnic S, Tijardovic M, Tsvetkov I, Varela MC, Vendramin GG \& Zlatanov T (2016) Evolution-based approach needed for the conservation and silviculture of peripheral forest tree populations. Forest Ecology and Management 375: 66-75.

Feliner GN (2011) Southern European glacial refugia: a tale of tales. Taxon 60: 365-372.

Felsenstein J (2013) PHYLIP: Phylogeny Inference Package. Version 3.695. http://evolution.genetics.washington.edu/phylip/doc/main.html.

Ferrazzini D, Monteleone I \& Belletti P (2007) Genetic variability and divergence among Italian populations of common ash (Fraxinus excelsior L.). Annals of Forest Sciences 64: 159-168.

Frankham R (2005) Genetics and extinction. Biological Conservation 126: 131-140.

Goudet J (1995) FSTAT (Version 1.2): a computer program to calculate F-statistics. Journal of Heredity 86: 485-486.

Guo SW \& Thompson EA (1992) Performing the exact test of Hardy-Weinberg proportion for multiple alleles. Biometrics 48: 361-372.

Hampe A \& Petit RJ (2005) Conserving biodiversity under climate change: the rear edge matters. Ecology Letters 8: 461-467.

Hamrick JL, Godt MJW \& Sherman-Broyles SL (1992) Factors influencing levels of genetic diversity in woody plant species. New Forest 6: 95-124.

Jump AP \& Peñuelas J (2006) Genetic effects of chronic habitat fragmentation in a wind-pollinated tree. Proceedings of the National Academy of Science of the United States of America 103: 8096-8100.
Kalinowski ST (2005) Do polymorphic loci require large sample sizes to estimate genetic distances? Heredity 94: 33-36.

Kramer AT \& Havens K (2009) Plant conservation genetics in a changing world. Trends in Plant Science 14: 599-607.

Leonardi S, Piovani P, Scalfi M, Piotti A, Giannini R \& Menozzi P (2012) Effect of habitat fragmentation on the genetic diversity and structure of peripheral populations of beech in Central Italy. Journal of Heredity 103: 408-417.

Lefèvre F, Koskela J, Hubert J, Kraigher H, Longauer R, Olrik DC, Schüler S, Bozzano M, Alizoti P, Bakys R, Baldwin C, Ballian D, Black-Samuelsson S, Bednarova D, Bordács S, Collin E, De Cuyper B, De Vries SMG, Eysteinsson T, Frýdl J, Haverkamp M, Ivankovic M, Konrad H, Koziol C, Maaten T, Notivol Paino E, Öztürk H, Pandeva ID, Parnuta G, Pilipovič A, Postolache D, Ryan C, Steffenrem A, Varela MC, Vessella F, Volosyanchuk RT, Westergren M, Wolter F, Yrjänä L \& Zaria I (2012) Dynamic conservation of forest genetic resources in 33 European countries. Conservation Biology 27: 373-384.

Liepelt S, Cheddadi R, de Beaulieu JL, Fady B, Gömöry D, Hussendörfer E, Konnert M, Litt T, Longauer R, Terhürne-Berson R \& Ziegenhagen B (2009) Postglacial range expansion and its genetic imprints in Abies alba (Mill.) - A synthesis from palaeobotanic and genetic data. Review of Palaeobotany and Palynology 153: 139-149.

Longauer R, Paule L \& Andonoski A (2003) Genetic diversity of southern populations of Abies alba Mill. Forest Genetics 10: 1-9.

Medail F \& Quezel P (1999) Biodiversity hotspots in the Mediterranean Basin: setting global conservation priorities. Conservation Biology 13: 1510-1513.

Minuto L, Grassi F \& Casazza G (2006) Ecogeographic and genetic evaluation of endemic species in the Maritime Alps: the case of Moehringia lebrunii and M. sedoides (Caryophyllaceae). Plant Biosystems 140: 146-155.

Miyamoto N, Fernandez-Manjarres JF, Morand-Prieur ME, Bertolino P \& Frascaria-Lacoste N (2008) What sampling is needed for reliable estimations of genetic diversity in Fraxinus excelsior L. (Oleaceae)? Annals of Forest Science 65: 403.

Montoya D (2008) Habitat loss, dispersal, and the probability of extinction of tree species. Communicate \& Integrative Biology 1: 146-147.

Morandini R \& Magini E (1975) Il materiale forestale di propagazione in Italia. Collana Verde $\mathrm{n}$. 34, MAF - Corpo Forestale dello Stato, Roma.

Mosca E, Eckert AJ, Di Pierro A, Rocchini D, La Porta N, Belletti P \& Neal DB (2012) The geographical and environmental determinants of genetic diver- 
sity for four alpine conifers of the European Alps. Molecular Ecology 21: 5530-5545.

Muller SD, Nagakawa T, de Beaulieu JL, Court-Picon M, Carcaillet C, Miramont C, Roiron P, Boutterin C, Ali AA \& Bruneton H (2007) Post-glacial migration of silver fir (Abies alba Mill.) in the south-western Alps. Journal of Biogeography 34: 876-899.

Pautasso M (2009) Geographical genetics and the conservation of forest trees. Perspectives in Plant Ecology, Evolution and Systematics 11: 157-189.

Peakall R \& Smouse PE (2006) GENALEX 6: genetic analysis in Excel. Population genetic software for teaching and research. Molecular Ecology Notes 6: 288-295.

Peakall R \& Smouse PE (2012) GenAlEx 6.5: genetic analysis in Excel. Population genetic software for teaching and research-an update. Bioinformatics 28: 2537-2539.

Pemberton JM, Slate J, Bancroft DR \& Barrett JA (1995) Nonamplifying alleles at microsatellite loci: a caution for parentage and population studies. Molecular Ecology 4: 249-252.

Petit RJ \& Hampe A (2006) Some evolutionary consequences of being a tree. Annual Review of Ecology, Evolution and Systematics 37: 187-214.

Piovani P, Leonardi S, Piotti A \& Menozzi P (2010) Conservation genetics of small relic populations of Silver fir (Abies alba Mill.) in the northern Apennines. Plant Biosystems 144: 683-691.

Piotti A, Leonardi S, Piovani S, Scalfi M \& Menozzi P (2009) Spruce colonization at treeline: where do those seeds come from? Heredity 103: 136-145.

Piry S, Luikart G \& Cornuet J-M (1999) BOTTLENECK: a computer program for detecting recent reductions in the effective population size using allele frequency data. Journal of Heredity 90: 502503.

Pritchard JK, Stephens M \& Donnelly P (2000) Inference of population structure using multilocus genotype data. Genetics 155: 945-959.

Reich PB \& Oleksyn J (2008) Climate warming will reduce growth and survival of Scots pine except in the far north. Ecology Letters 11: 588-597.

Rholf FJ (2006) NTSYS-PC. Numerical taxonomy and multivariate analysis system. Version 2.2. Setauket, NY, USA, Exeter Publishing. https:// www.exetersoftware.com/cat/ntsyspc/ntsyspc. html.
Rice KJ \& Emery NC (2003) Managing microevolution: restoration in the face of global change. Frontiers in Ecology and the Environment 1: 469-478.

Rosenberg NA, Burke T, Feldman MW, Friedlin PJ, Groenen MAM, Hillel J, Mäki-Tanila A, Tixier-Boichard M, Vignal A, Wimmers K \& Weigend $S$ (2001) Empirical evaluation of genetic clustering methods using multilocus genotypes from 20 chicken breeds. Genetics 159: 699-713.

Schönswetter P, Stehlik I, Holderegger R \& Tribsh A (2005) Molecular evidence for glacial refugia of mountain plants in the European Alps. Molecular Ecology 14: 3547-3555.

Slatkin M (1995) A measure of population subdivision based on microsatellite allele frequencies. Genetics 139: 457-462.

Thiel-Egenter C, Alvarez N, Holderegger R, Tribsch A, Englisch T, Wohlgemuth T, Colli L, Gaudeul M, Gielly L, Jogan N, Linder HP, Negrini R, Nikfeld H, Pellecchia M, Rioux D, Schönswetter P, Taberlet $\mathrm{P}$, van Loo M, Winkler M, IntraBioDiv Consortrium \& Gugerli F (2010) Break zones in the distributions of alleles and species in alpine plants. Journal of Biogeography 38: 772-782.

Tessier du Cros E, Màtyàs C \& Kriebel H (1999) Contribution of genetics to the sustained management of global forest resources - conclusions and recommendations: Forest Genetics and Sustainability, Forestry Sciences, vol. 63 (ed. by C Màtyàs) Kluwer Academic Publishers, Dordrecht, pp. 281-287.

Väli Ü, Einarsson A, Waits L \& Ellegren H (2008) To what extent do microsatellite markers reflect genome-wide genetic diversity in natural populations? Molecular Ecology 17: 3808-3817.

Van Oosterhout C, Hutchinson WF, Wills DPM \& Shipley P (2004) MiCRO-CHECKER: software for identifying and correcting genotyping errors in microsatellite data. Molecular Ecology Notes 4: 535-538.

Vidaković M (1991) Conifers, morphology and variation. Zdravko Zidovec, Zagreb.

Weir BS (1996) Genetic analysis data II. Sinauer Associates, Sunderland, Mass.

Williams CG (2010) Long-distance pine pollen still germinates after meso-scale dispersal. American Journal of Botany 97: 846-855. 